\title{
ANALYSIS OF IRF (INITIATION-RESPONSE-FEEDBACK) ON CLASSROOM INTERACTION IN EFL SPEAKING CLASS
}

\author{
Andi Rustandi, Ande Husni Mubarok \\ English Department, Galuh University, Ciamis \\ andru.unigal@yahoo.co.id
}

\begin{abstract}
This study aims at analyzing the reflection of IRF (Initiation-ResponseFeedback) in speaking class and investigating the dominant sequence among $I, R$ and $F$. IRF is a pattern of classroom interaction found by Sinclair and Coulthard in 1975 that stands for teacher initiation, students' response and feedback by teacher. Initiation is the movement in which teacher initiates an interaction to get the response of the students, then teacher gives feedback to the students' response. To obtain the data, the researcher conducted classroom observation in speaking class in one university in West Java. The result showed that student response becomes the dominant sequence of IRF in speaking class. Furthermore, it is recommended that the teachers should maintain the effectiveness of classroom interaction and give much opportunity to the students to take role in classroom verbal interaction through reflecting the IRF pattern in teaching learning process particularly in speaking classroom.
\end{abstract}

Keywords: IRF, classroom interaction, speaking class

\section{INTRODUCTION}

Speaking is considered as an important skill in our life. It has an important role to communicate with other people in daily life as stated by Thornburry (2005, p.1) that speaking is a part of daily life that we take it for granted. It refers to speaking is an important skill in order to communicate with other people. Therefore, students who learn foreign language, they have to accustom to communicate in target language. To make students accustomed to communicate in target language, Writers think that teacher can create interaction with students in classroom by using target language for the whole interaction. Interaction is an activity that usually conducts in classroom and it has an important role to build communication between teacher and students as stated by Walsh $(2011$, p. 23) that communication is a central to all classroom activity. 
Undoubtedly, Interaction cannot be separated from speaking. Interaction occurs every day in classroom activities between teacher and students. According to Brown (2001, p. 167), interaction is at the heart of communicative competence. It means that when students interact with each other, they receive input and produce output through language which is acquired by them as their communicative competence. It refers to interaction between teacher and students in classroom become a central in teaching and learning process. It can be caused by the exchange of thoughts, feelings or ideas as a result of input and output of language which is acquired by them through interaction.

Interaction between teacher and students has led into classroom interaction. According to Hall (2011, p. 11), classroom interaction is a term that used to analyze what goes on among people in classroom when language is involved. From the statement above, the term classroom interaction refers to the interaction between teacher-students and students-students in terms of language use during teaching and learning process in classroom. Teacher is not only interacts to students verbally but he or she interacts to students nonverbally as well. According to Robinson (2005, p. 17), interaction in the classroom is channeled through nonverbal interaction. It refers to body language between teacher and students in classroom. There are many functions of non-verbal interaction in the classroom, such as expressing emotion, communicating personal attitudes and supporting speech.

In speaking class, there are several specific features of verbal interaction as stated by Walsh (2011, p. 33) are as follows; (1) In direct-error correction, teacher interacts to students to correct errors which made by them during conversation occurred. Errors are corrected quickly and directly so this is far-less time-consuming, (2) In content feedback, teacher provides personal reactions to comments conversation that occurs naturally. It aims to provide oral fluency practice in which the use of conversational language is appropriate to their pedagogic purposes and language use.

The appropriateness of using conversational language creates an atmosphere that is conducive to learning and promotes students' involvement, 
Rustandi, Mubarok, Analysis of IRF (Initiation-Response-Feedback)...

(3) In checking for confirmation, teacher who seeks clarification and checks for confirmation has an opportunity to maximize learning potential since she or he does not always accepts the first contribution that students offered, (4) In extended wait-time, teacher gives a chance for students to manage their turntaking without intervention by teachers. By allowing students to manage their turn-taking, it will increase the number of students' response since it will lead to complex answers and students' involvement.

Classroom interaction plays important role in the teaching learning process. According to Dagarin (2004), classroom interaction can be defined as a two-way process between the participants in the learning process. The teacher influences the learners and vice versa. Moreover, she continues by quoting Brown's statement $(2001,165)$ that “...interaction is, in fact, the heart of communication: it is what communication is all about". Thus, learning will occur when there is co-operation between teacher and student which make communication take place.

According to Rustandi (2013), the definition of classroom interaction can be depicted from the pattern of classroom interaction in Table 1.

Table 1

Classroom Interaction Pattern

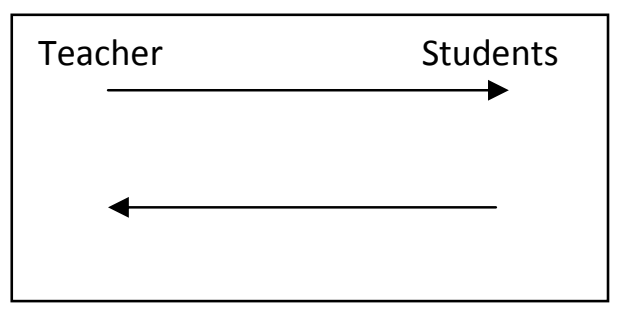

Communication is done because the interactants have some goals to achieve. In a classroom, communication takes place because teacher has something to transfer to the students, i.e. new knowledge. Likewise, students communicate with their teachers and peers because they want to get new knowledge and share their ideas. In this regard, the communication achieved through interactive communication between teacher -students and students teacher. 
Classroom interaction cannot be separated from the teacher and students. It has a certain pattern one of them is IRF pattern. This pattern stands for initiation-response-feedback, is a pattern of discussion between the teacher and learners. The teacher initiates, the learner responds, the teacher gives feedback (Sinclair \& Coulthard, 1975). The definition of three patterns can be traced through the following explanation.

Firstly is initiation (I), the movement in which teacher initiates an interaction, as stated by Dayag et al. $(2008$, p.5) initiation is the teacher ask a question or action to initiate students to do interaction in classroom. It is the effort of the teacher in pushing the students to drop their selves in a communication or interaction. According to Harmer $(2009$, p. 111), it is the stage "when the teacher has to do something is to get the students involved, engage and ready." It is also believed that the important way to create the interactive language classroom because it provides the stimuli for the student to interact continually.

Secondly response moves $(\mathrm{R})$, what is actually performed by the students following the initiation which produced by the teacher. Dayag et al (2008, p.5) state that response is represent the teacher initiate in response of initiation move by participants act. It means that the students do interact to response the teacher stimuli.

The last is feedback/follow up (F), the last exchange of a turn which aims to give feedback to students' response. According to Dayag et al. (2008, p.5) that feedback completes the cycle as it provides closure to the initiation and response. It means that students get immediately the correction or evaluation for their response.

Some studies related to IRF and classroom interaction have been investigated and several studies revealed that IRF can build active interaction between teacher and students in classroom interaction such as (Hong, 2009); (Pinkevience, 2011); and (Cohen, 2011). Generally, these studies showed that IRF pattern is the most sequence which occurred in classroom interaction. Nevertheless, the study about analysis of IRF reflection in classroom interaction and the dominant exchange among $\mathrm{I}, \mathrm{R}$ and $\mathrm{F}$ as not numerous as 
Rustandi, Mubarok, Analysis of IRF (Initiation-Response-Feedback)...

the number of those dealing with the study of the use of IRF. Therefore, this study is conducted to analyze the reflection of IRF (Initiation-ResponseFeedback) in speaking class and the dominant exchange among I, R and F.

\section{DISCUSSION}

The participant of this research is an English teacher and thirty five students of a speaking class in English department participated in this study. The reason of choosing this university particularly speaking class is because the class is active class and uses the sequence of interaction of IRF during teaching-learning process.

The data were gained through classroom observation. The observation was aimed to describe the reflection of IRF pattern when teacher-students interaction and analyze the dominant exchange of IRF. The observation administered three times in different times. Camera video was settled in the best position to record the classroom interaction, while the writer sat at the back of the classroom to take notes on what happened during teaching and learning process for capturing classroom interaction. Finally, the data obtained from the observation were analyzed by generalizing and interpreting the data.

Then the data were then analyzed qualitatively by employing some steps as transcribing, coding and analyzing. Transcribing is one way of analyzing data through observation. According to Cresswell (2008, p. 239) transcribing is the process of convert audiotape recordings in to the data. In this step, the result of recorded classroom interaction was transcribed as the main written source to be analyzed by the researcher.

Coding is the process of segmenting and labeling text to form descriptions and broad themes in the data. Besides, according to Nunan and Bailey (2009, p.260), interaction analysis system involves the identification of verbal and non- verbal interaction in terms of the coding and categorization of utterances. After completing the transcription, the researcher coded each number of utterances into the category based on Initiation-ResponseFeedback (IRF) pattern. The last is analyzing, that is the next step of analyzing 
data through observation. In this step, the writer analyzed the encoded transcription of the result of recorded classroom interaction into IRF pattern.

The result of this study revealed that the classroom interaction in speaking class reflected IRF pattern proposed by Sinclair and Coulthard (1975). The total numbers of interactions are 393 which are divided into 138 initiations, 177 student responses and 78 teacher feedbacks. These interactions occurred in teaching learning process. However, the whole of the interactions cannot be described fully because they have the same pattern. The three interactions below show the exchanges of IRF taken as sample from the 393 exchanges.

The examples of interaction between teacher and students can be seen in excerpt 1, 2 and 3.

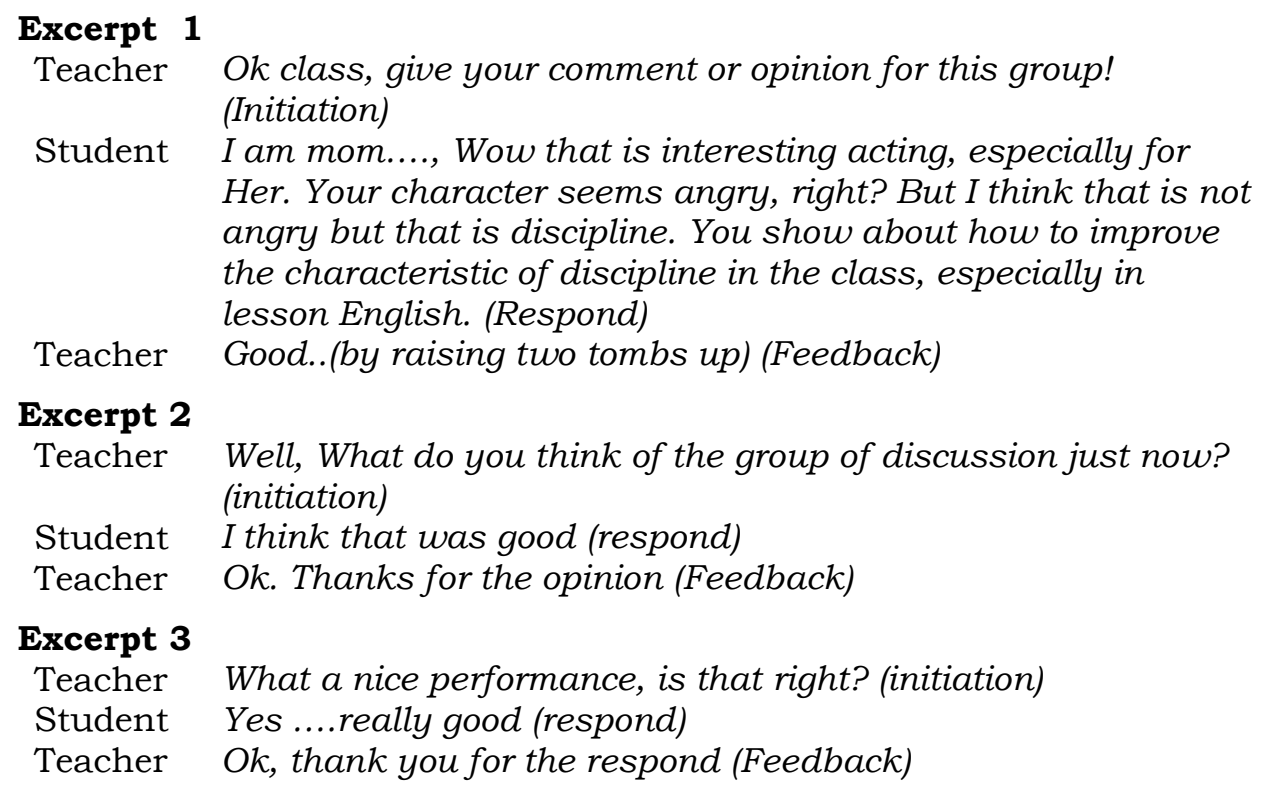

From the three brief excerpts above, it can be seen that in line 1 teacher asked students to give their opinion, in line 2 it can be seen that one of the students gave an opinion and in line 3 the teacher gave feedback by answering the student response. In this regard, the lecturer gives an initiation by asking the student to give a comment. Then, the student gives the response on the teacher initiation by giving a comment on the performance. Finally, the teacher gave feedback by giving verbal response toward the student opinion. 
Rustandi, Mubarok, Analysis of IRF (Initiation-Response-Feedback)...

In the pattern above, the teacher always initiate the interaction by giving question to the students. The initiation happened because of the students mostly passive in the speaking class discussion. They always waited what the teachers want to do. Then, the following pattern is response from the students. The response happened after the teacher initiation by the teacher. Student responds verbally or sometimes non-verbally. Then, the last pattern is feedback from the teacher to the students' response. The feedback usually used verbal and sometimes non-verbal act.

Every interaction is always initiated by the teacher question and then followed by the student response by giving opinion toward the teacher question and finally the teacher give feedback verbally and non-verbally toward the student opinion. The IRF pattern in classroom interaction in speaking class including the frequency of occurrences and also the percentage of types can be seen in the table 2 .

Table 2

IRF Pattern and Frequency Occurrences

\begin{tabular}{lcccccccc}
\hline \multirow{2}{*}{ Types } & \multicolumn{2}{c}{$\begin{array}{c}\text { First } \\
\text { Obs }\end{array}$} & \multicolumn{2}{c}{$\begin{array}{c}\text { Second } \\
\text { Obs }\end{array}$} & \multicolumn{2}{c}{$\begin{array}{c}\text { Third } \\
\text { Obs }\end{array}$} & Total & $\%$ \\
\cline { 2 - 8 } & $\mathrm{F}$ & $\%$ & $\mathrm{~F}$ & $\%$ & $\mathrm{~F}$ & $\%$ & & \\
\hline $\begin{array}{l}\text { Teacher } \\
\text { Initiation }\end{array}$ & 55 & 36,4 & 42 & 33,1 & 41 & 35,6 & 138 & 35,1 \\
\hline $\begin{array}{l}\text { Students } \\
\text { Response }\end{array}$ & 66 & 43,7 & 58 & 45,6 & 53 & 46,1 & 177 & 45 \\
\hline $\begin{array}{l}\text { Teacher } \\
\text { Feedback }\end{array}$ & 30 & 19,9 & 27 & 21,3 & 21 & 18,3 & 78 & 19,9 \\
\hline TOTAL & 151 & 100 & 127 & 100 & 115 & 100 & 393 & 100 \\
\hline
\end{tabular}

The table above shows that the students response is the highest score by 35,1\% calculated from three times observation. Then, at the second place is teacher initiation by doing three times observation totally $35 \%$. Finally the third place is teachers feedback in three times observation by total percentage 19,9 feedbacks. In this regard, the response of the students is the dominant pattern in the classroom interaction in speaking class rather than initiation and feedback. 
Regarding the highest score of student response, this pattern happened when the class had a group discussion. The class discussion was given by the teacher to develop students initiation, however, the initiation of the student were rarely occurred because of they were afraid of mistakes.

Teacher initiation is the second places due to the students' passiveness. It is because the discussion of the material that was given by the teacher was difficult to understand by the students. Finally, the initiation is the main focus of the teacher to overcome the death of the discussion.

Finally, the lowest score is teacher feedback. Teacher feedback is rarely happened due to the lack of response from the students. As a result the teacher only used verbal response to answer the student response. The feedback is useful for the teacher to motivate the students to initiate the interaction.

Regarding to the sequences pattern during classroom activities was teacher initiation which followed by student response and the last exchange was teacher feedback. In this case, asking question was used to initiate interaction to the students, so students could involve responses actively then teacher involved confirmation to the responses. It was related to Walsh (2006, p. 5), IRF (Initiation-Response-Feedback) is a pattern of interaction 'moves' in classroom that stands for $\mathrm{I}$ is teacher initiation, $\mathrm{R}$ is response by students and $\mathrm{F}$ is feedback by teacher. Furthermore, Tognini (2007, p. 132) states that IRF pattern is a common sequences in the language classroom when the teacher and students interact each other. The same result also showed by Pinkevicience (2011) that some teachers created opportunities for learner involvement through the implementation of IRF in classroom.

In line with the finding of the study above, this finding strengthen the previous argument of Kumpulainen and Wray (2002, p. 9) that IRF is the most widely known of typical classroom interaction patterns. In this interaction sequence, teacher controls interaction in classroom through initiating discussion and posing questions to students. After the students 
Rustandi, Mubarok, Analysis of IRF (Initiation-Response-Feedback)...

responded questions given by teachers, teacher finishes the interaction sequence by giving feedback on student's response. It is supported by Zhang (2012, p. 980) who found that more than 50\% of classroom exchanges or patterns are IRF. So that, IRF pattern is possible occurrences in the all of classroom lesson including speaking class.

Moreover, the second result of this study showed that the dominant occurred among $\mathrm{I}, \mathrm{R}$ and $\mathrm{F}$ in the classroom interaction on speaking class was students' responses. According to Dayag et al $(2008$, p.5) state that response is represent the teacher initiate in response of initiation move by participants act. It means that the students do interact to response the teacher stimuli. In this study the students gave contribution actively during the classroom lesson. In contrast with the findings of the study which is found the result that students response was dominant occurred in classroom lesson which caused by teacher effort to keep students participation, a research which conducted by Hong (2009) found that teacher initiation from the whole of classroom activities was dominant occurred. From the observation, Hong found that most of teaching learning activities was devoted to asking question by teacher to the students. According to Nakula as cited in Saikko (2007, p.24) assumed that nothing the exact structure of the IRF pattern that would lead to teacher or students dominance. It depends on the classroom interaction naturally. It means that IRF pattern gives same chance for both teacher and students to interact actively as well as dominantly in classroom.

Regarding the interaction during teaching and learning process in speaking classroom, Walsh $(2011$, p. 31) stated that interaction is an aid of showing how teachers can create opportunities for learning through their use of language and interactional resources. By verbal and noninteraction, teachers facilitate students' involvement by constructing language in which students are involved to create learning opportunities.

\section{CONCLUSIONS}

Based on the data analysis and the result of the study, the interaction during teaching learning activities was full of IRF pattern sequences. It can 
be concluded that the kind of teacher-student interaction in the speaking class is reflected by teacher initiation in which the teacher initiates the students by giving the questions, soliciting information and identifying the students who have the next turn to answer. In line with the types of IRF pattern, in the classroom activities the students' response is dominantly occurred. In the case of the dominance of student response, it will depend on what the material of the classroom lesson and how the teacher's way in provoking the students to be active. If the material in classroom lesson is quite easy the student participation will occurred frequently. On the other hand, if the teacher's way in provoking students by giving the initiation, it can make them interested, so the percentage of student response is increasing.

Finally, to achieve the better result in conducting classroom interaction in speaking class, the student should be more actively involved in the classroom. They should create their own opportunities and find strategies for getting practice in using and practicing the language, so they can participate and contribute during classroom lesson well. In addition, they should increase their motivation in studying speaking English through learning and practicing the language.

Therefore, it will be better for the next researcher to conduct the study not only about classroom IRF pattern but the other patterns as well. In addition, it will be better for further researchers to conduct the study about classroom interaction in which the other patterns on classroom interaction such as scaffolding and private speech pattern. Then, further researchers are expected to observe not only interaction pattern between teacherstudents but also interaction pattern among students.

\section{REFERENCES}

Brown, H. (2000). Teaching by principles: An interactive approach in language pedagogy (2nd ed.). New Jersey: Prentice Hall.

Cohen, Irit. (2011). Teacher-student interaction in classrooms of students with specific learning difficulties learning English as foreign language. Journal 
Rustandi, Mubarok, Analysis of IRF (Initiation-Response-Feedback)...

of Interactional research in communication disorders. Retrived fromhttps:/ / ore.exeter.ac.uk/repository/bitstream/handle/10036/4718 0/Teacher\%20 Child \%20Interaction.pdf?sequence $=5$.

Cohen, Louis, Manion Lawrence \& Morrison, Keith.(2005). Research method in education (5th ed.). New York : Routledge Falmer.

Creswell, John W. (2008). Education research: planning, conducting and evaluating quantitative and qualitative research (3rd ed.). New Jersey:Pearson Prentice Inc.

Dayag, D.T., Gustilo, L. E., Flores, E.G., Borlongan, A. M., \& Carreon, M. C. (2008). Classroom discourse in selected philippine primary schools. British Council

Fraenkel, Jack R., \& Wallen, Norman E. (2012). How to design and evaluate research in education (8th ed.). San Fransisco: Mc. Graw Hill Companies Inc.

Goronga, Pedzisai. (2013). The nature and quality of classroom verbal Zimbabwe. Savap journal, 4, (2). Retrieved from http : / / www. savap. org. pk/ journals / ARInt. / Vol. 4(2) /2013(42-45).pdf

Hall, Graham. (2011). Exploring English language teaching: language in action. New York: Routledge.

Harmer, Jeremy. (2007). The practice of English language teaching (4th ed.). Pearson Longman.

Hong, H. (2009). Teacher-student interaction in singapore classrooms: a corpus-based study. Center for research in pedagogy and practice, National Institute of Education Nanyang Technological university, Singapore,Retrieved from http://www.nanyang.edu.journal.com/corpus. pdf

Kumpulainen, Kristina.,\& Wray, David. (2002). Classroom interaction and social learning from theory to practice. New York: Routledge Falmer.

Nunan, D., \& Bailey, K., M., (2009). Exploring second language classroom research. Canada: Cengage learning.

Pinkeviciene. (2011). Triadic dialogue in efl classroom: embedded extension. Studies about languages. Retrieved from http : / http:// www. Celea .org. $\mathrm{cn} /$ teic/60/60-56.pdf.

Richards, Jack C. (2008). Teaching listening and speaking from theory to practice. New York: Cambridge.

Robinson, Helja. (2005). The ethnography of empowerment: the transformative power of classroom interaction. London: The Falmer Press. 


\section{EduLite}

Journal of English Education, Literature, and Culture

Rustandi, Andi (2013). Meaning negotiation between teachers and students in fledgling international standardized school. International journal of English and education. Vol. 2, Issue 3, July 2013.

Saikko, V. (2007). Different student-strategies for interactional power in the irf pattern in an EFL classroom. A Postgraduate Thesis. University of Jyvaskyla. Retrieved from https://www.google.co.id /url? sa=t\&rct= $\mathrm{j} \& \mathrm{q}=\& \mathrm{esrc}=\mathrm{s} \& \quad$ source $=$ web\&cd $=2 \& v e d=0 \mathrm{CB} 4 Q \mathrm{FjAB} \& u r l=h t \mathrm{tps} \% 3 \mathrm{~A} \% 2 \mathrm{~F} \%$ 2Fjyx.jyu.fi\%2Fdspace\%2Fbitstream\%2Fhandle\%2F $123456789 \% 2 \mathrm{~F} 7429$ \%2FURN_NBN_fi_jyu-2007629.pdf\%3Fsequence\%3D1\&ei= 3a7FU43mDc 2XuASEkoCwDA\&usg=AFQjCNGtguOOcelWREypGmnTfjEAjd6CkA\&bvm= bv.71126742,d.c2E.

Sinclair, J. M., \& Coulthard, M. (1975). Towards an analysis of discourse: the english used by teachers and pupils. London: Oxford University Press.

Thornbury, Scott. (2005). How to teach speaking. Essex: Longman.

Walsh, Steve. (2006). Investigating classroom discourse. London: Routledge Taylor and Francis Group.

Walsh, Steve. (2011). Exploring classroom discourse language in action. London: Routledge Taylor and Francis Group.

Woodside, Arch G. (2010). Case study: research, methods, practice. Emeral Group Publishing Limited.

$\mathrm{Yu}, \mathrm{R}$. (2008). Interaction in EFL classes. Asian social science. Vol 4(2). Retrieved from http://www.ccsenet.org/journal /index.php/ elt/article/ download/1597.

Zhang. P. (2012). Interactive patterns and teacher talk features in an EFL reading class in a Chinese University. Theory and practice in language studies. 5, 980-981. Retrieved from http://ojs. Academypublisher.com/ index.php/tpls/article/viewFile/tpls0205980988/4935. 